The impact of knowledge management system quality on the usage continuity and recommendation intention

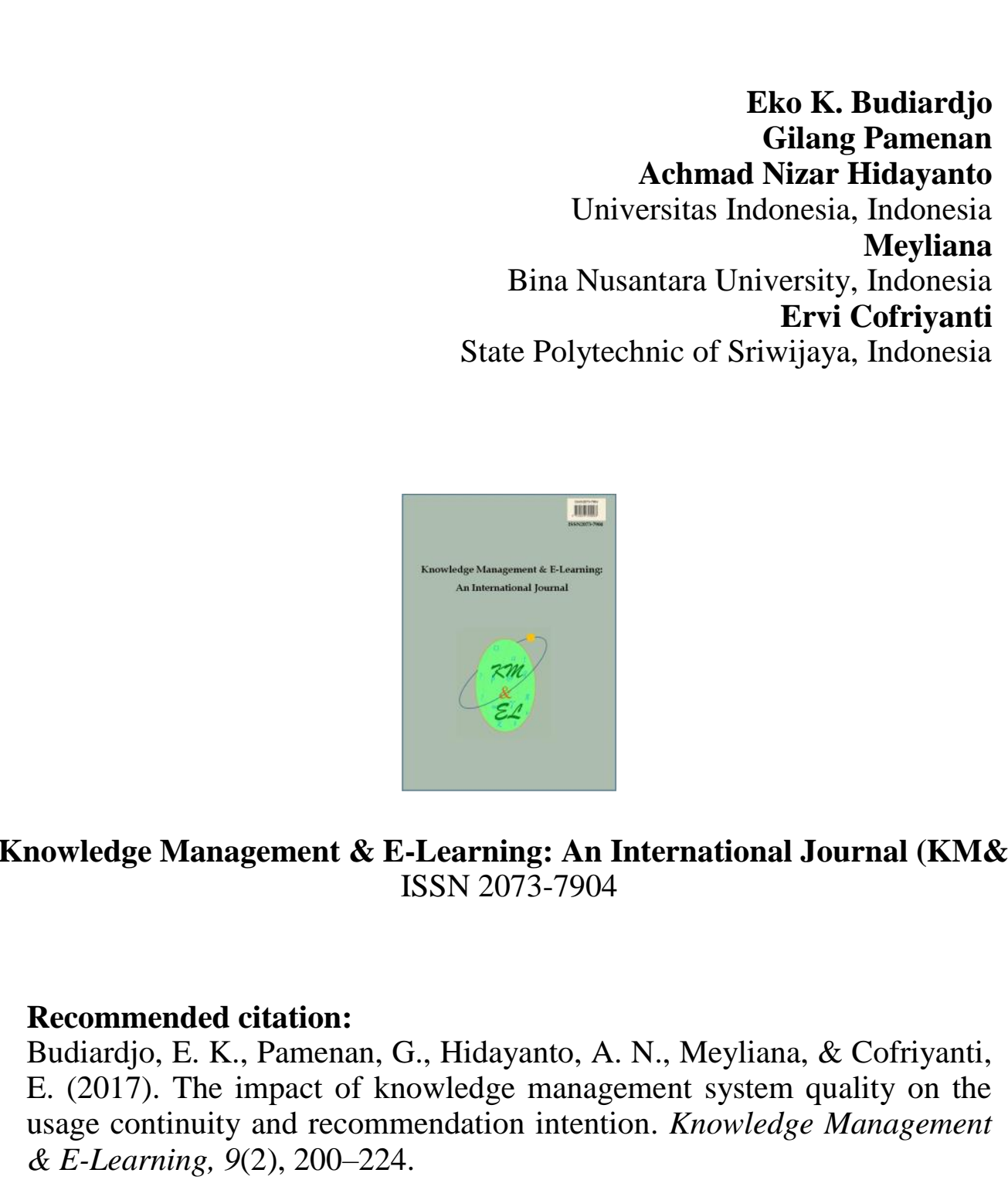




\title{
The impact of knowledge management system quality on the usage continuity and recommendation intention
}

\author{
Eko K. Budiardjo \\ Faculty of Computer Science \\ Universitas Indonesia, Indonesia \\ E-mail: eko@cs.ui.ac.id

\section{Gilang Pamenan} \\ Faculty of Computer Science \\ Universitas Indonesia, Indonesia \\ E-mail: gilang.pamenan@gmail.com
}

\section{Achmad Nizar Hidayanto*}

Faculty of Computer Science

Universitas Indonesia, Indonesia

E-mail: nizar@cs.ui.ac.id

\section{Meyliana}

School of Information Systems

Bina Nusantara University, Indonesia

E-mail: meyliana@binus.edu

\section{Ervi Cofriyanti}

State Polytechnic of Sriwijaya, Indonesia

E-mail: ervi@polsri.ac.id

*Corresponding author

\begin{abstract}
This study aimed to examine the influence of knowledge management system (KMS) quality on users' continuance intention. The research model was developed by integrating the concept of DeLone and McLean's information systems (IS) success model with the expectation confirmation model. To examine the developed model, a survey was conducted with 131 respondents from three companies that had implemented a KMS. The data were analyzed using the partial least square (PLS) method. The study demonstrated that both system quality and information/knowledge quality influence all the factors that drive the continuance intention regarding KMS usage, namely perceived usefulness, satisfaction, and trust. Moreover, satisfaction proved to have an impact on users' recommendation intention concerning the KMS. Therefore, companies should improve the KMS quality in order to drive employees to continuously use the KMS and recommend it to others.
\end{abstract}


Keywords: Knowledge management; Knowledge management systems; System quality; Knowledge quality; Continuance intention; IS success model; Expectation confirmation model; Post adoption behavior

Biographical notes: Eko K. Budiardjo has been the faculty member of the Faculty of Computer Science - University of Indonesia since 1985. Majoring in Software Engineering as professional track record, he has made some scientific contribution such as Software Requirement Specification (SRS) patterns representation method, ZEF Framework, and FrontCRM Framework. Graduated from Bandung Institute of Technology (ITB) in 1985, holds Master of Science in Computer Science from the University of New Brunswick Canada in 1991, and awarded Philosophical Doctor in Computer Science from Universitas Indonesia in 2007. Currently he is the Chairman of The Indonesian ICT Profession Society (IPKIN).

Gilang Pamenan received his bachelor degree in Information Systems from Universitas Indonesia. His research interests are related to information systems and knowledge management. Currently he is working as a business analyst in a private company in Jakarta, Indonesia.

Achmad Nizar Hidayanto is Head of Information Systems/Information Technology Stream, Faculty of Computer Science, Universitas Indonesia. He received his $\mathrm{PhD}$ in Computer Science from Universitas Indonesia. His research interests are related to information systems/information technology, elearning, e-commerce, e-government, information systems security, change management, knowledge management and technology diffusion/adoption.

Meyliana has been the faculty member of the School of Information Systems Bina Nusantara University since 1997. Her research interests are business process management, enterprise system, customer relationship management, ebusiness and information system development. Graduated from Master in Management of Information Systems from Bina Nusantara University. She received her PhD in Computer Science from University of Indonesia. Currently she is the Deputy Vice Rector Operational of Alam Sutera Campus and Rector's Office Manager, Bina Nusantara University.

Ervi Cofriyanti obtained her master degree in Information Technology from Universitas Indonesia. Her interests include mathematics, social informatics, IS/IT governance and knowledge management. Currently, she is working as lecturer at State Polytechnic of Sriwijaya.

\section{Introduction}

Knowledge management (KM) can be described as an effort to capture factually explicit information, information and tacit knowledge, or information stemming from employees that will help the organization to achieve its goals (Becerra-Fernandez \& Sabherwal, 2010). Jennex (2005) defines KM as a process for selecting knowledge based on past decisions in order to assist in the decision-making process and thus improve the organization's effectiveness.

There are numerous factors that could encourage an organization to implement KM. According to Becerra-Fernandez and Sabherwal (2010), a high employee turnover rate within an organization is one of the most important reasons for implementing KM. 
With KM, companies do not need to worry about the turnover rate, since the knowledge of former employees is captured by the KM process. Moreover, through effective KM, an organization can avoid repetitive work and mistakes (Farzaneh \& Shamizanjani, 2014). Rapid market changes also encourage companies to implement KM. Organizations can use customer knowledge and identify patterns in the market to help in decision making.

The KM process can be supported by information technology (Becerra-Fernandez \& Sabherwal, 2010; Maccoby, 2003; Wu \& Wang, 2006) in the form of a knowledge management system (KMS) (Wu \& Wang, 2006). A KMS can support the KM process in various ways, including making finding necessary information faster, integrating information into a comprehensive body of knowledge (Moos, Beimborn, Wagner, \& Weitzel, 2011), providing an integrated repository to store all the organization's knowledge (Bera \& Wand, 2009; Leung, Shamsub, Tsang, \& Au, 2015), collaborating with other employees in a discussion (Abdelrahman, Papmichail, \& French, 2011), and identifying an expert to ask about necessary information or knowledge (Wu \& Wang, 2006). One of the main benefits of a KMS is the availability of relevant, accurate, and timely knowledge, which can be used in various forms so as to help companies and individuals effectively solve problems and make decisions (Tiwana \& Bush, 2005). The decision maker can find the information stored in the company via the KMS and can thus work to increase the company's effectiveness and competitiveness (Tiwana \& Bush, 2005).

According to Wu and Wang (2006), a KMS is a type of information system. Similar to other information systems, a KMS that is not adequately used by a company will not lead to any positive impacts (Sucahyo, Utari, Budi, Hidayanto, \& Chahyati, 2016; Wu \& Wang, 2006). Any type of information technology implemented by a company will only fulfill its promise if it is used continuously by employees (He \& Wei, 2008). According to Li and Liu (2011), prior research has shown that a company's behavior after receiving an information system is a vital factor in supporting the company's efforts to compete in a competitive marketplace. The company needs to encourage its employees to continuously use the system so that the company is able to gain positive impacts ( $\mathrm{Li} \&$ Liu, 2011). Studies on continuous information system usage are therefore just as important as studies on the intention to use and information system acceptance (Kim, Hong, Min, \& Lee, 2011; Li \& Liu, 2011). Unfortunately, most prior studies only discussed the early stages of system usage (Kim et al., 2011). Relatively few studies have assessed the following stages (post-adoption stages) to determine users' behavior after they have used an information system, including KMSs.

This research study aims to identify the factors that encourage users' willingness to continuously use a KMS. Research concerning KMS usage continuity is still rare (He $\&$ Wei, 2008). We use the expectation confirmation model (Bhattacherjee, 2001) because many studies have demonstrated its capacity to explain continuance usage behavior in relation to information systems. In addition, we integrate the model with DeLone and McLean's information systems (IS) success model (DeLone \& McLean, 2003) to examine the impact of KMS quality on users' post-adoption stage behavior, namely their usage continuance and recommendation intention. Recommendation intention is another variable taken from the research of $\mathrm{Li}$ and Liu (2001). According to Chea and Luo (2008), the recommendation intention variable is one of the loyalty dimensions that is as important as the willingness to continuously use a system. Recommendation is an affectdriven behavior. The work motivation literature has made the connection between an affective response and affect-driven behaviors. In particular, the affective events theory (AET) posits that affective reactions in the workplace determine affect-driven behaviors. According to the AET, positive affect fostered helping behavior on the part of co-workers 
(Weiss \& Cropanzano, 1996). Recommendation behavior is similar to helping behavior in that both forms of behavior result in selfless acts in which individuals assist others (Chea \& Luo, 2008). In relation to knowledge management systems, recommendation behavior can motivate people to promote the system to others through word of mouth behavior.

The remainder of the paper is organized as follows. Section 2 discusses the theories underlying this research, including the KMS concept, DeLone and McLean's (2003) IS success model, and the expectation-confirmation model. Section 3 establishes the research model proposed in this study and relates it to the continuance intention concerning KMS usage. Section 4 describes the research method, including respondent selection, the research instrument, and the data analysis tools. Section 5 presents the results of the research, while section 6 discusses the theoretical and practical implications of the research. The final section presents the conclusions of the research.

\section{Literature review}

\subsection{Knowledge management system}

A knowledge management system (KMS) is a KM technology and integration mechanism built to support the KM process (Alavi \& Leidner, 2001; Becerra-Fernandez \& Sabherwal, 2010). Wu and Wang (2006) stated that a KMS is an information system used to manage knowledge. Information technology (IT) can support the KM process in various ways such as helping employees to trade knowledge more easily, identifying an expert to ask about necessary information or knowledge, and accessing information derived from past projects (Alavi \& Leidner, 2001). However, KM does not play a special role in IT (Alavi \& Leidner, 2001).

According to Becerra-Fernandez and Sabherwal (2010), depending on its process, a KMS can be classified as one of four types, namely a knowledge discovery system, knowledge capture system, knowledge sharing system, or knowledge application system. A knowledge discovery system supports the new tacit and explicit knowledge development process from information and data or previous knowledge synthesis. A knowledge capture system supports the reception of explicit and tacit knowledge reception stored in three knowledge vaults: artifacts, people's minds, and an organization's entity. A knowledge sharing system supports the communication of explicit and tacit knowledge (referred to as exchange and socialization, respectively) to others. A knowledge application system supports the knowledge application process. Knowledge application is a process for utilizing knowledge without moving the knowledge itself.

\subsection{DeLone and McLean's IS success model}

The success of an information system is a multi-dimensional concept that can be measured from various perspectives. DeLone and McLean (1992) made an important breakthrough after reviewing the prior literature concerning information system success and proposing a comprehensive model of information system success. Their model consists of six variables: system quality, information quality, satisfaction, use, individual impact, and organizational impact. 
According to the model, system quality and information quality encourage people to use the system, as well as creating satisfaction based on system usage. Further, use and satisfaction affect each other. Both variables also impact each individual. The technology variables are represented by system quality and information quality, while the system effectiveness can be measured by use, users' satisfaction, individual impact, and organizational impact (DeLone \& McLean, 2003).

System quality is measured by several factors, including whether or not there are bugs, a good user interface, usage easiness, and the quality and maintenance of program code (Seddon, 1997). Information or knowledge quality is a dimension that describes the information quality created by the system (Seddon, 1997). The information quality can be measured in terms of information accuracy, completeness, relevance, precision, and upto-dateness (Bailey \& Pearson, 1983; Ives, Olson, \& Baroudi, 1983). The use variable can be measured by the system usage frequency (Seddon, 1997). Users' satisfaction is defined as users' feeling or behavior regarding the impact they receive from various factors in a particular situation (Bailey \& Pearson, 1983). Individual impact is the users' perception of how important or beneficial the information system they are using is (DeLone \& McLean, 2003), while organizational impact measures how far the system usage impacts the organization's overall performance (DeLone \& McLean, 2003).

Ten years later, DeLone and McLean renewed their model. There is one addition to the new model, namely service quality, which reflects the importance of the service available to support the system's success, especially in the e-commerce field. Additionally, individual impact and organization impact are merged into one variable referred to as the net benefit.

Many studies use DeLone and McLean's IS success model as a reference point when creating a knowledge management success model, including Liu (2003), Wu and Wang (2006), Kulkarni, Ravindran, and Freeze (2007), Hidayanto, Limupa, Junus, and Budi (2015), and Pai and Zou (2013). It is important to recognize that there are two conceptual differences when making the transition: one is the move from information to knowledge and the other is the switch from a single information system to KM system implementation. Both of these differences lead to changes in the characterization of the constructs involved, as well as in the relationships between them in a success model (Kulkarni et al., 2007). Sometimes, knowledge management success models not only use one model (e.g., DeLone and McLean's model), but actually combine several models, for example, combine DeLone and McLean's model with the task-technology fit (TTF) Model (Pai \& Zou, 2013), or adding DeLone and McLean's model to the construct of organizational support (leadership, incentive, co-worker and supervisor) (Kulkarni et al., 2007). In addition, Liu (2003) used Jennex and Olfman's (2003) knowledge system success model, which modified DeLone and McLean's revised IS success model by adding the constructs of technological resource, KM level, KM form as system quality; the constructs of KM strategy/process, richness, and linkages as knowledge quality; and the constructs of management support, IS KM service quality, and user KM service quality as service quality.

\subsection{Expectation confirmation model}

Bhattacherjee (2001) researched the factors that can encourage users' willingness to continuously use an information system. To do so, Bhattacherjee (2001) adopted a model used in the marketing world known as the expectation confirmation model (ECM). The ECM is a model developed by Oliver (1980) to identify the variables that encourage customers to return and buy the same product. The four identified variables are 
expectation, performance perception, confirmation, and satisfaction. This framework showed that product repurchase or continuous service usage really depends on the user's satisfaction with the product and service (Oliver, 1980, 1993).

Bhattacherjee (2001) described how a user's decision to continuously use an information system is similar to an individual's decision to return and buy a product or service. The decision is based on the impact of three things: (1) early reception of the information system or purchase; (2) experience of the system information or product's performance; and (3) potential change of earlier decision. Considering Oliver's model, Bhattacherjee (2001) then proposed to reuse the information system with variables such as perceived usefulness, confirmation, satisfaction, as well as reuse.

The expectation confirmation model has been used in various studies of consumers' behavior to investigate consumers' satisfaction and post-purchase behavior (e.g., the willingness to return and repurchase or complain), as well as to study market service (Dabholkar, Shepard, \& Thorpe, 2000; Oliver, 1980, 1993). The theory has been applied in various contexts, including purchase intention on mobile apps (Hsu \& Lin, 2015), continuance intention to use electronic textbooks (Stone \& Baker-Eveleth, 2013), continuance intention to use web-based services (Lee \& Kwon, 2011), and continuance intention to use IPTV (Lin, Wu, Hsu, \& Chou, 2012).

Many studies have used the expectation confirmation model, including Chea and Luo (2008), Li and Liu (2011), and Basten, Schneider, and Michalik (2013). Similar to DeLone and McLean's IS success model, the expectation confirmation model is also occasionally combined with other models or additional constructs. For example, Chea and Luo (2008) and Li and Liu (2011) used the ECM with the additional variables of perceived ease of use and recommendations to analyze the post-adoption behavior of eservice users, whereas Basten et al. (2013) used expectation confirmation theory (ECT) to analyze the extent to which software developers' expectations regarding knowledge contributions are fulfilled by organizations.

\section{Hypotheses development and research model}

This research relies on the expectation confirmation theory developed by Bhattacherjee (2001), which includes:

- $\quad$ Perceived usefulness: as a form of performance expectation created by Oliver (1980, 1993).

- Confirmation: using two variables from DeLone and McLean (2003), namely information quality and system quality. Service quality is not used because it refers to the initial model of DeLone and McLean (1992). In addition, the usage of these two variables also refers to the research of Wu and Wang (2006). In the context of knowledge management, service quality is not fit for use.

- Satisfaction.

- Continuance intention to use.

\subsection{KMS quality's impact on perceived usefulness, satisfaction, and trust}

DeLone and McLean (2003) recognized that an information system's performance can determine the success of that system. KMS quality can be measured in terms of system quality and possessed information or knowledge quality. System quality is defined as 
how well the KMS performs the knowledge management process function, how well the knowledge is coded, and how well the KMS is supported by the associated information technology and infrastructure staff (Jennex \& Olfman, 2003). According to $\mathrm{Wu}$ and Wang (2006), system quality can be determined based on whether or not there are errors in the system, how easy the information system is to use, the response time, the degree of flexibility, and the level of stability. Information or knowledge quality is a dimension that ensures contextually accurate knowledge can be captured by the appropriate person when it is needed (Jennex \& Olfman, 2003). Information or knowledge quality can be measured in terms of information accuracy, completeness, relevance, precision, and upto-dateness (Kim et al., 2011; Tona, Carlsson, \& Eorn, 2012; Widiyanto, Sandhyaduhita, Hidayanto, \& Munajat, 2016). In this research study, information quality is combined with knowledge quality because information quality can be used as a success measure for a traditional information system, while in the KMS context, the distinction between knowledge and information depends on both the context and the user. One processor's knowledge could be another's information; the knowledge provided to a given processor for a certain task at a certain time may be the only information available for another task or at a different time (Wu \& Wang, 2006).

System quality and information or knowledge quality can increase users' perceptions of the usefulness of the system. When accessing a KMS, the better the information the users obtain, the more beneficial the KMS will be seen to be (Wu \& Wang, 2006). A good quality KMS that has less errors and bugs, as well as being easy to learn and easy to use, will also enhance the perception that the KMS is beneficial for users. A system full of errors and bugs will certainly not be accessed maximally in order to improve users' work. Additionally, Jennex and Olfman (2003) noted the relation between system quality and information or knowledge quality and the perceived usefulness of KMS usage in nuclear power companies.

Therefore, it is surmised that there is a positive relationship between system quality and information or knowledge quality and users' perceived usefulness, as formulated by the following hypotheses:

H1: System quality has a positive impact on perceived usefulness.

H2: Information or knowledge quality has a positive impact on perceived usefulness.

Some researchers in the marketing field have recognized that product and service performance is the main factor that determines consumers' satisfaction (Kim, Zhao, \& Yang, 2008). Product performance is equivalent to the quality perception of an information system (DeLone \& McLean, 2003), which has been empirically confirmed in various studies (Kim et al., 2011). A good KMS system will satisfy its users. Good information or knowledge quality will also build users' satisfaction. When users access a KMS and gain the accurate and precise data they needed, the users will gain satisfaction (Tona et al., 2012). This issue has also been addressed in studies by Wu and Wang (2006), Jennex (2005), Kim, Xu, and Koh (2004), and Bossen, Jensen, and Udsen (2013).

Thus, it is surmised that there is a positive relation between system quality and information or knowledge quality and users' satisfaction. Therefore, the research posits the following hypotheses:

H3: System quality has a positive impact on satisfaction.

H4: Information or knowledge quality has a positive impact on satisfaction.

A good KMS, aside from improving satisfaction and perceived usefulness, can also improve trust in the system. Trust can be defined as a specific belief in a competency 
of a reliable party (Gefen, 2004). When users feel the KMS performance is good, the system will be perceived as having characteristics that provide benefits when used (Kim et al., 2011). This triggers trust in the KMS. This theory is supported by the studies of Belanger, Hiller, and Smith (2002) and McKnight, Choudhury, and Kacmarc (2002).

This indicates that there is a relation between system quality and information or knowledge quality and users' trust in a system, as the following hypotheses suggest:

H5: System quality has a positive impact on trust.

H6: Information or knowledge quality has a positive impact on trust.

\subsection{Perceived usefulness's impact on satisfaction, continuance intention, and recommendation}

Perceived usefulness is an ex-post expectation variable or an expectation that is triggered after users use a system. This variable is adapted from the technology acceptance model developed by Davis, Bagozzi, and Warshaw (1989). Perceived usefulness has been empirically proven to consistently affect users, both in the early reception stage and after usage (Bhattacherjee, 2001). In the KMS context, users who gain benefit from the KMS performance as measured by a reliable system and useful information that serves to improve productivity will consider that the KMS is satisfactory. This is supported by the research of Lee and Kwon (2011), Li and Liu (2011), Chea and Luo (2008), Lin, Wu, and Tsai (2005), and Thong, Hong, and Tam (2006), who all identified a positive relation between perceived usefulness and users' satisfaction.

Based on that, the suggestion that there is a positive relation between both variables can be formulated into the following hypothesis:

\section{H7: Perceived usefulness has a positive impact on satisfaction.}

Perceived usefulness is one of the main motivating factors that encourage information system users to continuously use a system. After the users use the system and recognize that it can bring benefits to their work, they will be encouraged to keep using the system (Bhattacherjee, 2001). KMS usage is intended to help employees in managing the knowledge they have, thereby improving their performance. This performance improvement will likely lead to rewards from the organization. The effort to improve performance in order to gain rewards is, according to Bhattacherjee (2001), not dependent on a certain time or behavior, whether it is the early stages or later stages of system usage. This theory is supported by the research of Stone and Baker-Eveleth (2013) into electronic textbook usage continuity, as well as by the studies of Lin et al. (2005), Lee and Kwon (2011), and Li and Liu (2011).

Based on the above, it is surmised that there is a positive relationship between continuance intentions regarding KMS usage and perceived usefulness, as suggested in this hypothesis:

\section{H8: Perceived usefulness has a positive impact on continuance intention.}

According to Chea and Luo (2008), there are several post-system usage behaviors that are just as important as continuance intention, including word of mouth (WOM) or recommendation. A recommendation from users who have already used a system can encourage potential users to also use that system (Li \& Liu, 2011). Moreover, according to Chea and Luo (2008), the decision to offer a recommendation is determined by the positive impact that users obtain. On the contrary, Chea and Luo (2008) stated if users 
obtain a negative impact, they will make a complaint. In the KMS context, a positive impact can encourage users to offer a recommendation depending on the perceived usefulness those users achieve ( $\mathrm{Li} \& \mathrm{Liu}, 2011$ ). Users who feel the benefit and positive impact of KMS usage will be encouraged to make a recommendation to other users.

Considering this, the present study surmises that there is a relationship between perceived usefulness and users' intention to make a recommendation, which can be formulated as the following hypothesis:

H9: Perceived usefulness has a positive impact on recommendation.

\subsection{Satisfaction's impact on trust, continuance intention, and recommendation}

A good experience in the past can trigger trust (Hashim, Tan, \& Andrade, 2012; Kim et al., 2011; Cofriyanti \& Hidayanto, 2013). In the KMS context, a KMS that provides satisfaction to users can enhance their perception that the KMS is competent or trustworthy. Other researchers have also proved that past satisfaction can trigger trust, including Gefen (2004) and Singh and Sirdeshmukh (2002). In Chiu, Hsu, Lai, and Chang's (2012) research concerning the influence of trust on repeated online purchases, it was found that satisfaction encourages customers to trust an online store.

Thus, it can be assumed that there is a positive relationship between satisfaction and users' trust in a KMS, as formulated in the following hypothesis:

H10: Satisfaction has a positive impact on trust.

Satisfaction can be defined as an evaluation of product quality compared to the expectation prior to purchasing the product (Kim et al., 2011). Satisfaction is key to building long-term relationships as well as leading to repurchases (Chea \& Luo, 2008). Szymanski and Henard (2001) found that users who are satisfied with a product's performance are less likely to pick another product or option. Lee and Kwon (2011) also found empirical evidence that users who are satisfied with a service will use that product frequently. Aside from encouraging continuous usage, satisfaction also encourages users to voluntarily offer positive information to other people (i.e., recommendation) (Li \& Liu, 2011). Satisfaction with KMS usage will surely encourage employees to keep using the KMS on a daily basis. This satisfaction can even encourage users to share the positives of a particular KMS. There is a lot of information that can help people with their work, and it is easy to use. In other words, people can also recommend that others use a KMS.

Based on the above, it is surmised that there is a positive relationship between satisfaction and continuance intention regarding KMS usage, which is formulated in the following hypotheses:

H11: Satisfaction has a positive impact on continuance intention.

H12: Satisfaction has a positive impact on recommendation.

\subsection{Trust's impact on continuance intention and recommendation}

According to McKnight et al. (2002), trust's effect on trusting intention has already been confirmed. Kim et al. (2011) found that trust positively affects the commitment to use. Users' trust can increase their loyalty to the system, or alternatively encourage users to leave the system. Ercis, Unal, Candan, and Yildirim (2012) and Graf and Perrien (2005) stated that trust is the main antecedent of building long-term relationships, as well as 
being an antecedent of building loyalty and the intention to repurchase and recommend. Trust increases users' assurance regarding the expected behavior and reduces harmful worries (Kim et al., 2011). In the KMS context, someone who is expecting a benefit when using a KMS can be encouraged with trust. With that trust, users will be certain that the KMS will keep providing the necessary benefit and not disappoint. The benefit gained increases the trust rate of a KMS's users regarding the system's capability. In other words, competency fulfilment and the benefit gained by users from the KMS will trigger trust in the KMS, and that trust will drive the intention to offer recommendations to others.

Based on the above explanation, it is assumed that there is a positive relationship between KMS users' trust and their continuance intention regarding KMS usage and recommendation to others. Thus, the following hypotheses are proposed:

H13: Trust has a positive impact on continuance intention.

H14: Trust has a positive impact on recommendation.

\subsection{Continuance intention's impact on recommendation}

Recommendation and continuance intention are two post-adoption behavioral aspects (Chea \& Luo, 2008; Li \& Liu, 2011). Both are behaviors that are affected by positive impacts and other aspects with similar characteristics. Other than having the same trigger factor, both variables are also related to each other. Li and Liu (2011) stated that the intention to continuously use a KMS affects users' willingness to offer a recommendation. Li and Liu (2011) also found that satisfaction and loyalty are factors that determine positive word of mouth. According to Li and Liu (2011), continuance intention is seen as a loyalty dimension in relation to information systems. When users have the intention to continue using a system, they have gained a lot of benefit from using the system and are thus motivated to keep using it and promoting it by word of mouth. Therefore, Li and Liu (2011) concluded that continuance intention is a factor that triggers the willingness to make a recommendation. The same has been stated by Choi (2009).

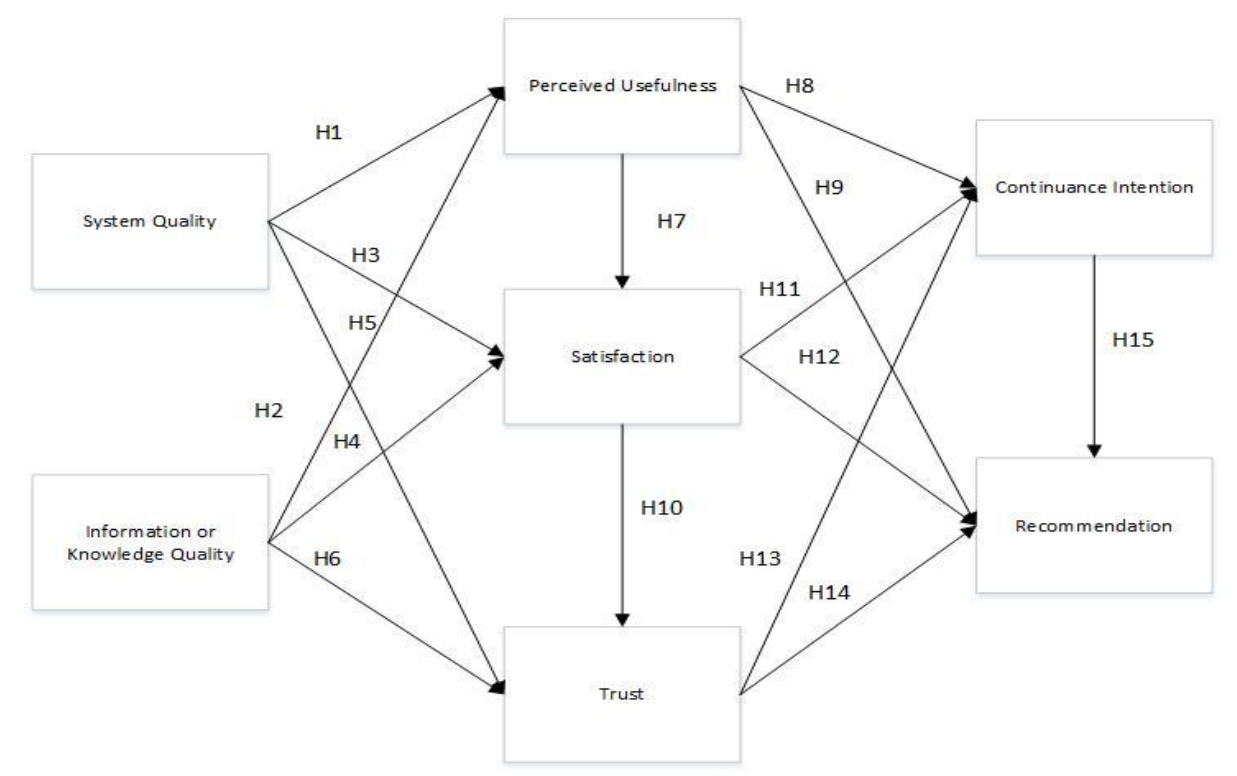

Fig. 1. The research model 
It is hence surmised that continuance intention regarding KMS usage affects users' intention to make recommendations to others. Therefore, the following hypothesis is formulated:

\section{H15: Continuance intention has a positive impact on recommendation.}

The research model's design can be seen in Fig. 1.

\section{Methodology}

\subsection{Data collection and analysis procedure}

The first step in this research study was to contact ten companies that have already implemented a KMS. However, of those ten companies, only three were willing to be involved in the study. The three companies that expressed a willingness to participate are power plant, internet infrastructure, and IT consultant companies with a total of 131 respondents. The sampling in each company was achieved using the purposive sampling and snowball sampling methods. Purposive sampling is a sampling method used to meet certain goal (Trochim, 2000). The sample is not random, but is instead picked according to the research criteria, namely those who have used their company's KMS. Their knowledge management systems have features that support four types of KMS process: knowledge discovery, knowledge capture, knowledge sharing, and knowledge application process. For example, they use repositories of information, best practices, and lessons learned to support the knowledge discovery process; chat groups or discussion board features helps to support the knowledge capture process; the expertise locator feature and repositories of information help to support the knowledge sharing process; and the capture and transfer of experts' knowledge helps to support the knowledge application process. Table 1 displays the indicators that the study is applied to all KMSs, not to just one or some of the KMS types. Therefore, the research results can be applied to all types of KMS. The questionnaires were distributed via the human resource division of each company and sent to all relevant employees who were willing to participate.

The data analysis method used in this research is the partial least square (PLS) method. The PLS method does not require normality assumption. It is also insensitive to sample size considerations. Its estimation approach handles both very small and very large samples with greater ease than structural equation modelling (SEM). The PLS method is particularly useful in generating estimates with very small samples (sample size of 30 observations or less) where SEM programs are not applicable (Hair, Black, Babin, \& Anderson, 2010). The major aim of the PLS method, which has been widely applied in marketing and business research, is to maximize the explained variance of the dependent latent variables (Hair, Ringle, \& Sarstedt, 2011). According to Hair et al. (2011), PLS-SEM is a promising method that offers enormous potential for SEM researchers, especially in the marketing and management information systems disciplines. PLS-SEM is, as the name suggests, a more regression-based approach that minimizes the residual variances of the endogenous constructs.

\subsection{Research instrument}

This research used the questionnaire approach to gain data and test the proposed model. The questionnaire consisted of two parts, the respondent's profile and the main questions. In the first part, the respondents were asked to fill in data according to their profile and 
answer some questions related to their KMS usage. In the second part, the respondents were asked to state their agreement with the given statements using a five-point Likert scale, with each point representing disagree (1), less agree (2), neutral (3), agree (4), and really agree (5). Table 1 shows the operation of each research variable.

Table 1

Research instruments

\begin{tabular}{|c|c|c|}
\hline Variables & Indicators & References \\
\hline System Quality (SQ) & $\begin{array}{l}\text { SQ1. The KMS is easy to } \\
\text { use. } \\
\text { SQ2. The KMS is easy to } \\
\text { learn (user friendly). } \\
\text { SQ3. The KMS is stable, } \\
\text { rarely down/ crashed. } \\
\text { SQ4. The KMS has a good } \\
\text { response time and is in the } \\
\text { tolerable range. } \\
\text { SQ5. The KMS runs its } \\
\text { functions well and is reliable } \\
\text { (i.e., errors are rare). }\end{array}$ & $\begin{array}{l}\text { Wu and Wang (2006); Kim et } \\
\text { al. (2011); DeLone and } \\
\text { McLean (2003). }\end{array}$ \\
\hline $\begin{array}{l}\text { Information/Knowledge } \\
\text { Quality }(I Q)\end{array}$ & $\begin{array}{l}\text { IQ1. The KMS has consistent } \\
\text { wording and phrasing. } \\
\text { IQ2. The KMS provided } \\
\text { important and useful } \\
\text { information for my work. } \\
\text { IQ3. The KMS provided } \\
\text { useful, easy to understand, } \\
\text { and easily applicable } \\
\text { information or knowledge. } \\
\text { IQ4. The KMS provided the } \\
\text { information or knowledge in } \\
\text { a timely fashion when I } \\
\text { needed it. } \\
\text { IQ5. The KMS provided } \\
\text { accurate information. } \\
\text { IQ6. The KMS provided up- } \\
\text { to-date information. }\end{array}$ & $\begin{array}{l}\text { Wu and Wang (2006); Kim et } \\
\text { al. (2011); } \\
\text { Bossen et al. (2013). }\end{array}$ \\
\hline Perceived Usefulness (PU) & $\begin{array}{l}\text { PU1. KMS usage is so useful } \\
\text { for my work. } \\
\text { PU2. KMS usage helps me to } \\
\text { improve my productivity. } \\
\text { PU3. KMS usage helps me to } \\
\text { finish my work quickly. } \\
\text { PU4. KMS usage helps me to } \\
\text { improve my work } \\
\text { effectively. } \\
\text { PU5. KMS usage helps me to } \\
\text { access a lot of useful } \\
\text { information. }\end{array}$ & $\begin{array}{l}\text { He and Wei (2008); Tha, Poo, } \\
\text { and Yu (2009); Davis et al. } \\
\text { (1989); Lin et al. (2005). }\end{array}$ \\
\hline Satisfaction (SAT) & SAT1. Overall, I am satisfied & Wu and Wang (2006); Lee and \\
\hline
\end{tabular}




\begin{tabular}{|c|c|c|}
\hline & $\begin{array}{l}\text { with the KMS I am using. } \\
\text { SAT2. I am satisfied with my } \\
\text { decision to use the KMS. } \\
\text { SAT3. I am happy with my } \\
\text { decision to use the KMS. } \\
\text { SAT4. Overall, I am satisfied } \\
\text { with my experience using the } \\
\text { KMS. }\end{array}$ & $\begin{array}{l}\text { Kwon (2011); Chiu et al. } \\
(2012) \text {. }\end{array}$ \\
\hline Trust (TRU) & $\begin{array}{l}\text { TRU1. After using the KMS, } \\
\text { I feel it is a reliable system. } \\
\text { TRU2. I trust the KMS's } \\
\text { capability. } \\
\text { TRU3. The KMS is a reliable } \\
\text { system. } \\
\text { TRU4. The KMS is really } \\
\text { competent and efficient in } \\
\text { providing information or } \\
\text { knowledge. }\end{array}$ & $\begin{array}{l}\text { Zhang, Fang, Wei, and Chen } \\
\text { (2010); Morgan and Hunt } \\
\text { (1994); } \\
\text { Kim et al. (2011). }\end{array}$ \\
\hline Continuance Intention (CI) & $\begin{array}{l}\text { CI1. I intend to keep using } \\
\text { the KMS rather than stop. } \\
\text { CI2. I have the intention to } \\
\text { keep using the KMS rather } \\
\text { than looking for other } \\
\text { alternatives. } \\
\text { CI3. If possible, I will keep } \\
\text { using the KMS. } \\
\text { CI4. I will use the KMS } \\
\text { often. } \\
\text { CI5. I am planning to keep } \\
\text { using the KMS. }\end{array}$ & $\begin{array}{l}\text { Bhattacherjee (2001); Dong, } \\
\text { Cheng, and Wu (2014); Chea } \\
\text { and Luo (2008). }\end{array}$ \\
\hline Recommendation (REC) & $\begin{array}{l}\text { REC1. I intend to share the } \\
\text { positive sides of the KMS I } \\
\text { am using with others. } \\
\text { REC2. I plan to recommend } \\
\text { the KMS to others. } \\
\text { REC3. I intend to get my } \\
\text { friends to use the KMS. }\end{array}$ & Chea and Luo (2008). \\
\hline
\end{tabular}

\section{Results and discussion}

\subsection{Respondents' demographics}

This research study classifies the respondents' profile into several categories, namely gender, age, length of service, education level, frequency of KMS access, and time spent accessing the KMS. From the questionnaires, the total number of samples from the three companies is 131 respondents. Table 2 summarizes the respondents' demographics. 
Table 2

Respondents' demographics

\begin{tabular}{|c|c|c|c|c|c|}
\hline \multicolumn{6}{|c|}{ Categories } \\
\hline Gender & $\begin{array}{l}\text { Male: } \\
72 \%\end{array}$ & $\begin{array}{l}\text { Female: } \\
28 \%\end{array}$ & & & \\
\hline Age & $\begin{array}{l}<25 \text { years: } \\
12 \%\end{array}$ & $\begin{array}{l}25-35 \\
\text { years: } 50 \%\end{array}$ & $\begin{array}{l}36-45 \text { years: } \\
11 \%\end{array}$ & $\begin{array}{l}>45 \text { years: } \\
27 \%\end{array}$ & \\
\hline $\begin{array}{l}\text { Length } \\
\text { service }\end{array}$ & $\begin{array}{l}<1 \text { year: } \\
5 \%\end{array}$ & $\begin{array}{l}\text { 1-5 years: } \\
38 \%\end{array}$ & $\begin{array}{l}6-10 \text { years: } \\
22 \%\end{array}$ & $\begin{array}{l}11-15 \\
\text { years: } 3 \%\end{array}$ & $\begin{array}{l}>15 \text { years: } \\
32 \%\end{array}$ \\
\hline Education level & $\begin{array}{l}\text { High } \\
\text { school: } 5 \%\end{array}$ & $\begin{array}{l}\text { Bachelor's } \\
\text { degree: } 64 \%\end{array}$ & $\begin{array}{l}\text { Master's } \\
\text { degree: } 20 \%\end{array}$ & $\begin{array}{l}\text { Doctoral } \\
\text { degree: } 0 \%\end{array}$ & $\begin{array}{l}\text { Vocational } \\
\text { degree: } 11 \%\end{array}$ \\
\hline $\begin{array}{l}\text { Frequency of } \\
\text { KMS access }\end{array}$ & $\begin{array}{l}\text { Every day: } \\
11 \%\end{array}$ & $\begin{array}{l}\text { Once a } \\
\text { week: } 14 \%\end{array}$ & $\begin{array}{l}\text { Once every } \\
\text { two weeks: } \\
8 \%\end{array}$ & $\begin{array}{l}\text { Once per } \\
\text { month: } \\
13 \%\end{array}$ & $\begin{array}{l}\text { Less than } \\
\text { once per } \\
\text { month: } 54 \%\end{array}$ \\
\hline $\begin{array}{lr}\text { Time spent } \\
\text { accessing the } \\
\text { KMS }\end{array}$ & $\begin{array}{l}<15 \\
\text { minutes: } \\
34 \%\end{array}$ & $\begin{array}{l}15-30 \\
\text { minutes: } \\
41 \%\end{array}$ & $\begin{array}{l}30 \text { minutes to } \\
1 \text { hour: } 17 \%\end{array}$ & $\begin{array}{l}\text { 1-2 hours: } \\
4 \%\end{array}$ & $>2$ hours: $4 \%$ \\
\hline
\end{tabular}

\subsection{Measurement model test}

This test is conducted to assess the extent to which a manifest or indicator variable can represent a latent variable. The PLS measurement model evaluation is conducted in three stages: the convergent validity test, the discriminant validity test, and the reliability test. The first step in the evaluating measurement model is testing the convergent validity. According to Ghazali and Latan (2012), the convergent validity test is conducted to see whether a manifest variable has a high correlation with the latent variable. The convergent validity test is conducted by examining the average variance extracted (AVE) score. According to Hair et al. (2011), the AVE score has to be higher than 0.5. As seen in Table 3, all the latent variables in this study have an AVE score higher than 0.5 , thus fulfilling one of the convergent validity tests.

Table 3

Measurement model evaluation results

\begin{tabular}{rrrccc}
\hline Variable & \multicolumn{2}{c}{ Loading Factor } & AVE & Cronbach's Alpha & Composite Reliability \\
\hline \multirow{4}{*}{ CI } & CI1 & 0.915545 & & & \\
& CI2 & 0.881497 & & 0.948352 & 0.960359 \\
& CI3 & 0.890285 & 0.828999 & & \\
& CI4 & 0.930717 & & & \\
& CI5 & 0.933217 & & & \\
& IQ1 & 0.804048 & & & \\
& IQ2 & 0.871037 & & & \\
IQ & IQ3 & 0.904442 & 0.927614 & \\
& IQ4 & 0.888621 & 0.735454 & \\
& IQ5 & 0.862723 & & & 0.96229 \\
& IQ6 & 0.809675 & & & \\
& PU1 & 0.929214 & & &
\end{tabular}




\begin{tabular}{|c|c|c|c|c|c|}
\hline \multirow{3}{*}{ REC } & REC1 & 0.955495 & & & \multirow{3}{*}{0.969389} \\
\hline & REC2 & 0.969331 & \multirow[t]{2}{*}{0.913475} & \multirow[t]{2}{*}{0.952583} & \\
\hline & REC3 & 0.942259 & & & \\
\hline \multirow{4}{*}{ SAT } & SAT1 & 0.941538 & \multirow{5}{*}{0.895896} & \multirow{5}{*}{0.961228} & \multirow{4}{*}{0.971767} \\
\hline & SAT2 & 0.936301 & & & \\
\hline & SAT3 & 0.963525 & & & \\
\hline & SAT4 & 0.944484 & & & \\
\hline \multirow{5}{*}{ SQ } & SQ1 & 0.862566 & & & \multirow{5}{*}{0.944564} \\
\hline & SQ2 & 0.918706 & \multirow{4}{*}{0.773281} & \multirow{4}{*}{0.926449} & \\
\hline & SQ3 & 0.849597 & & & \\
\hline & SQ4 & 0.86409 & & & \\
\hline & SQ5 & 0.899943 & & & \\
\hline \multirow{4}{*}{ TRU } & TRU1 & 0.944248 & \multirow{4}{*}{0.875703} & \multirow{4}{*}{0.952525} & \multirow{4}{*}{0.965715} \\
\hline & TRU2 & 0.934883 & & & \\
\hline & TRU3 & 0.959686 & & & \\
\hline & TRU4 & 0.90344 & & & \\
\hline
\end{tabular}

According to Hair et al. (2011), aside from the AVE, the convergent validity test can also be determined based on the loading factor score in the indicator path of the latent variable. Table 3 depicts all the indicators that have a loading factor score higher than 0.7 . Thus, all the indicators in this research study passed the convergent validity test.

Next, a reliability test has to be conducted. The reliability test is conducted to determine whether the indicators in the latent variable are consistent in terms of representing the latent variable (Chin, 2010). According to Ghazali and Latan (2012), the reliability test can be conducted by determining the Cronbach's alpha and composite reliability scores. Both scores must be higher than 0.7. As seen in Table 3, all the variables passed the reliability test because they have Cronbach's alpha and composite reliability scores higher than 0.7 . Considering both test results, the present research instrument is concluded to be both valid and reliable.

\subsection{Structural model test}

After evaluating the measurement model, the next step is to determine the path significance in order to prove the hypothesis created by conducting the structural model evaluation. This step consists of two parts, namely examining the R-square $\left(R^{2}\right)$ from the endogenous latent variable and examining the t-statistic score from the bootstrap method.

The testing of the $\mathrm{R}^{2}$ is conducted to determine how far an exogenous latent variable affects the endogenous latent variable (Chin, 2010).

Table 4

$\mathrm{R}^{2}$ score for each endogenous variable

\begin{tabular}{lc}
\hline & $\mathrm{R}^{2}$ \\
\hline CI & 0.842044 \\
PU & 0.789962 \\
REC & 0.716435 \\
SAT & 0.843281 \\
TRU & 0.779978 \\
\hline
\end{tabular}


According to Chin (1998), if the value of $\mathrm{R}^{2}$ is greater than 0.67 , then it can be concluded that the exogenous latent variable has a strong impact on the endogenous latent variable. If the value of $\mathrm{R}^{2}$ is between 0.33 and 0.67 , then it is categorized as medium impact, while if the value of $\mathrm{R}^{2}$ is less than 0.33 , then it is categorized as low impact. Table 4 demonstrates that all the endogenous latent variables have a score higher than 0.67. Thus, it can be concluded that the exogenous latent variable has a strong impact on the endogenous latent variable. The hypothesis allocation via the path that connects the exogenous latent variable to the endogenous latent variable is quite significant.

Next, the path coefficient and t-statistic tests are used to determine the relationship significance between the latent variables, and whether or not a hypothesis is acceptable is examined. According to Hair et al. (2011), one latent variable has a significant influence on another latent variable if it has a t-value score of 1.65 with a significance score of $10 \%$. A path coefficient score between -0.1 and 0.1 is considered to be insignificant. After evaluating the structural model, it can be concluded whether or not a hypothesis is acceptable. The path coefficient and t-value results, as well as the hypothesis test results, can be seen in Table 5 .

\section{Table 5}

Path coefficient, t-value, and hypothesis test results

\begin{tabular}{ccccc}
\hline Hypothesis & Path & $\begin{array}{c}\text { Path } \\
\text { Coefficient }\end{array}$ & T-Value & Conclusions \\
\hline H1 & SQ -> PU & 0.220013 & 2.829002 & Hypothesis is accepted \\
H2 & IQ -> PU & 0.702101 & 9.666773 & Hypothesis is accepted \\
H3 & SQ -> SAT & 0.398058 & 5.464959 & Hypothesis is accepted \\
H4 & IQ -> SAT & 0.21088 & 2.009682 & Hypothesis is accepted \\
H5 & SQ -> TRU & 0.326903 & 3.184233 & Hypothesis is accepted \\
H6 & IQ -> TRU & 0.241664 & 2.283894 & Hypothesis is accepted \\
H7 & PU -> SAT & 0.369962 & 3.370492 & Hypothesis is accepted \\
H8 & PU -> CI & 0.510984 & 4.75927 & Hypothesis is accepted \\
H9 & PU -> REC & 0.064558 & 0.417109 & Hypothesis is rejected \\
H10 & SAT -> TRU & 0.364093 & 2.73428 & Hypothesis is accepted \\
H11 & SAT -> CI & 0.170065 & 1.689926 & Hypothesis is accepted \\
H12 & SAT -> REC & 0.391271 & 2.539215 & Hypothesis is accepted \\
H13 & TRU -> CI & 0.282733 & 2.73219 & Hypothesis is accepted \\
H14 & TRU -> REC & -0.026635 & 0.209528 & Hypothesis is rejected \\
H15 & CI -> REC & 0.45025 & 2.850229 & Hypothesis is accepted \\
\hline
\end{tabular}

\subsection{Discussion}

According to the hypothesis test, system quality and information or knowledge quality both affect users' intention to continuously use a KMS. This research determined that perceived usefulness, satisfaction, and trust all influence users to continuously use a KMS, 
with the perceived usefulness acting as the strongest antecedent. The results also revealed that information or knowledge quality is the main antecedent of perceived usefulness. Further, this research found that intention to recommend is only affected by satisfaction with using the KMS, not by trust or perceived usefulness.

\subsubsection{The impacts of KMS performance}

According to the hypothesis test, KMS performance as represented by system quality and information or knowledge quality affects users' perceived usefulness. Information or knowledge quality has a significant impact on users' perceived usefulness. This is in line with the hypothesis that users will consider a KMS to be useful if there is a lot of information that can help with their work and is presented in a good way. Aside from that, KMS quality also affects perceived usefulness. This is in agreement with the findings of previous research by Jennex (2005) and Wu and Wang (2006).

KMS performance was also shown to have an impact on users' satisfaction level. A good KMS will surely generate satisfaction in its users. A KMS with a low error and crash rate will make users feel comfortable using the system. Additionally, when users access a KMS and gain accurate and precise knowledge, they will gain satisfaction (Tona et al., 2012). This finding is in line with previous research that identified a positive relation between system performance and users' satisfaction level, including the studies of Tona et al. (2012), Jennex (2005), Wu and Wang (2006), Kim et al. (2011), and Bossen et al. (2013).

Aside from affecting perceived usefulness and satisfaction level, a KMS can also affect the trust impact on its users. According to Flavian, Guinaliu, and Gurrea (2006), trust can be measured by the extent to which a company can meet its clients' needs. In this research study, it was shown that a KMS that provides information and knowledge that meets users' needs can improve users' trust in the system. Further, according to Kim et al. (2004), trust in a website is triggered by the quality of the web system, while this research also proved that system quality on the part of a KMS triggers users to increase their trust in that KMS. Thus, this study supports the findings of previous research that there is a positive relation between system performance and trust level (Belanger et al., 2002; Chiu et al., 2012; Kim et al., 2004; McKinney et al., 2002; McKnight et al., 2002).

\subsubsection{Perceived usefulness's impact on satisfaction, continuance intention, and recommendation}

Perceived usefulness is a variable adapted from research by Bhattacherjee (2001) to identify what triggers users' motivation to continuously use an information system. Additionally, perceived usefulness triggers satisfaction and trust in a KMS. In this research, it can be seen that perceived usefulness has an impact on users' satisfaction and continuance intention to use a KMS. This result agrees with the findings of research conducted by Chea and Luo (2008), Lee and Kwon (2011), Li and Liu (2011), Stone and Baker-Eveleth (2013), Lin et al. (2005), and Bhattacherjee (2001).

However, the finding showed that perceived usefulness does not affect the intention to offer a recommendation to others. Li and Liu (2011) found that perceived usefulness in the e-service context can be a motivating factor for a customer to make a recommendation to others to use the particular e-service. In this research, it was shown that a KMS that offers a lot of benefits to its users does not encourage those users to make recommendations to others, which is in line with the research by Kulkarni et al. 
(2007) and Pai and Zou (2013). The difference in research scope could be one reason why the hypothesis is unproven in this study. In the studies by Chea and Luo (2008) and Li and Liu (2011), the research scope covered the post-adoption behavior of e-service users, whereas this research, as well as the studies by Kulkarni et al. (2007) and Pai and Zou (2013), focuses on KMS users. Additionally, knowledge is one of the competitive advantages for an individual (Standing \& Benson, 2000), since knowledge can be seen as a political basis for power and identity. Someone who gains useful knowledge from a KMS can therefore improve his/her competitive advantage. This could result in a knowledge management barrier that creates an unwillingness on the part of certain users to offer recommendations to use the KMS so that others do not gain the same competitive advantage (Standing \& Benson, 2000).

\subsubsection{Satisfaction's impact on trust, continuance intention, and recommendation}

According to Flavian et al. (2006), users' satisfaction has a relationship with the extent to which a website can achieve the required competency. In the KMS context, it can be said that a KMS that provides satisfaction to users can enhance their perception that the KMS is competent and reliable. This research study showed that there is a positive relation between users' satisfaction and trust level. This finding is in line with previous research by Gefen (2004), Singh and Sirdeshmukh (2002), Chiu et al. (2012), Kim et al. (2011), and Hashim et al. (2012).

In terms of the information system scope, it has been shown that satisfaction can also be a factor that affects users' continuous usage intention (Bhattacherjee, 2001). Satisfaction is the main antecedent of improving users' intention to continuously use an information system (Bhattacherjee, 2001). Other researchers, including Li and Liu (2011), Stone and Baker-Eveleth (2013), Kim et al. (2011), Chea and Luo (2008), Tha et al. (2009), and Chiu et al. (2012), have proved the positive relation between satisfaction level and continuance intention with regard to KMS usage. In this research study, satisfaction with a KMS was shown to encourage users' willingness to continuously use that KMS. A user who is satisfied with the system quality and who gains useful information will be willing to keep using the KMS.

The satisfaction felt by users has also been shown to encourage their willingness to offer recommendation to others to use a KMS. Satisfaction is shown to have a greater effect on users' likelihood of offering a recommendation than on their continuance intention regarding KMS usage. This finding supports the results of previous research by Chea and Luo (2008), Mooradian and Oliver (1997), Casaló, Flavián, and Guinaliu (2008), and $\mathrm{Li}$ and Liu (2001), who all concluded that satisfaction can encourage someone to make a recommendation to others.

\subsubsection{Trust's impact on continuance intention and recommendation}

Users' trust level can improve their loyalty to a system or, alternatively, encourage them to leave a system. Ercis et al. (2012) stated that trust is the main antecedent of building long-term relationships, as well as an antecedent of building loyalty. Furthermore, DeWitt, Nguyen, and Marshall (2008) stated that trust is one of the factors that can affect loyalty behavior. Loyalty behavior can be seen as the willingness to continuously use a system and make positive recommendations to others (Chea \& Luo, 2008; Dick \& Basu, 1994; Ercis et al., 2012; Reichheld, 2003). Research such as the studies by Chu and Kim (2011), DeWitt et al. (2008), Ranaweera and Prabhu (2003), Shiau and Luo (2012), and 
Graf and Perrien (2005) has identified a positive relation between trust and continuance intention regarding KMS usage as well as offering recommendations to others.

In this research study, the level of trust in the KMS was shown to encourage users to continuously use the KMS, although it did not have a significant relation with their willingness to make a recommendation to others. Prior research such as the study by Graf and Perrien (2005) has investigated the trust variable in terms of its impact on the relation between companies and external parties such customers. Graf and Perrien (2005) found that trust can encourage customers to make recommendations to others. However, this does not seem sufficient to affect the difference in the findings in the KMS research context. This research study was conducted with internal company employees. A user, in this context an employee, does not require trust in order to trigger the willingness to convince other employees to use the KMS. It is suspected that the trust factor is more suitable in other context such as e-commerce or marketing that involve the relationship between a company and its customers.

\subsubsection{Continuance intention's impact on recommendation}

In this research study, the continuance intention regarding KMS usage was shown to encourage users to offer recommendations to others. This is in line with the findings of prior studies, which concluded there is a relationship between these two loyalty dimensions.

According to $\mathrm{Li}$ and $\mathrm{Liu}$ (2011), when information system users display the intention to keep using a system, they have gained a lot of benefit from using that system, which triggers the motivation to both reuse the system and promote the system through word of mouth. A study by Choi (2009) also found that users who have a high intention to keep using a system have a positive relationship with the intention to recommend that system to other via word of mouth.

\section{Implications}

Based on the results of this research, some implications for future research and practice can be suggested.

\subsection{Theoretical implications}

This research used the expectation confirmation model developed by Bhattacherjee (2001) as well as the information system success model developed by DeLone and McLean (2003). In using these two models, this research attempted to build a model to identify the factors that encourages users to continuously use a KMS and offer recommendations to others.

This research used the theory developed by Bhattacherjee (2001) to identify the factors that encourage users to continuously use an information system. In this research, perceived usefulness was shown to be the post-usage expectation that has to be fulfilled in order to trigger continuous system usage. Perceived usefulness was empirically shown to have the most significant impact on the continuance intention regarding KMS usage. Additionally, the satisfaction factor was shown to have the same effect as expectation confirmation theory. 
In addition to identifying a relationship between perceived usefulness and satisfaction and users' continuance intention, the expectation confirmation model also concludes that there is a positive relation between perceived usefulness and satisfaction. This research strengthens the theory, since perceived usefulness was shown to have a relation with satisfaction. This research also determined a positive relation between trust and continuance intention regarding KMS usage. This confirms the theory developed by Li and Liu (2011).

In this research study, system quality and information or knowledge quality in a KMS were shown to affect perceived usefulness, satisfaction, and trust. Both factors also indirectly affected continuance intention regarding KMS usage. This finding supports DeLone and McLean's (2003) notion that system quality and information quality are key to implementing information system. DeLone and McLean's (2003) found that those two factors encourage both satisfaction and continuance intention. This research proved that there is a relation between system quality and information quality and satisfaction, as well as an indirect relation with continuance intention regarding KNS usage. Additionally, this research also confirmed the theories developed by other researchers, including Li and Liu (2011), who stated that there is a relation between trust and continuance intention regarding KMS usage.

\subsection{Practical implications}

This research proved that a KMS's perceived usefulness, satisfaction, and trust can be the main motivators for increasing the continuance intention regarding KMS usage. The three factors have to be supported by good KMS quality. This research identified a positive relation between KMS performance and satisfaction level, perceived usefulness, and trust level. KMS performance in this research is represented by the system quality and the information or knowledge quality. Therefore, companies need to pay attention to both system quality and information or knowledge quality in order to encourage employee to continuously use the KMS. In addition, a good level of trust between employees can also encourage the sustainable usage of the KMS. Therefore, companies need to enhance KMS quality so that the trust level is higher. It has also been proved that the satisfaction felt by users when accessing a good KMS encourages them to make recommendations to others.

Companies can improve the system quality of their KMS by creating a user interface that is easy to use, designing a user friendly appearance, improving KMS stability to minimize crashes and downtime, and improving the response time. Furthermore, companies need to improve information or knowledge quality by providing useful, easy to understand, applicable, accurate, and up-do-date information in a consistent format.

\section{Conclusions}

This research study resulted in a number of findings related to KMS quality and its relation with continuance intention regarding KMS usage. Based on the data analysis, the main factor that encourages users to continuously use a KMS is perceived usefulness. Perceived usefulness has the most significant impact on the continuance intention regarding KMS usage. Satisfaction and trust were also shown to affect users' intention to continuously use a KMS. Additionally, satisfaction was shown to affect users' intention to offer recommendations to others. KMS quality as represented by system quality and 
information or knowledge quality was shown to affect perceived usefulness, satisfaction level, and users' trust. Both latent variables were shown to be KMS quality factors that indirectly affect the continuance intention regarding KMS usage. In this research, trust and perceived usefulness were not shown to have a significant impact on the willingness to offer recommendations to others. This research involved a relatively small sample size, so we decided to use the PLS method to process the data. In studies such as Dijkstra (1983), the use of the PLS method has been criticized due to it being an unreliable estimation and testing tool. Therefore, increasing the number of respondents and changing the tool usage to covariance-based SEM such as Amos/Lisrel should be trialed in the future.

\section{Acknowledgements}

This research is supported by "Penelitian Unggulan Perguruan Tinggi' Research Grant (No. 1062/UN2.R12/HKP.05.00/2016) from the Directorate General of Higher Education, Ministry of Research, Technology, and Higher Education, the Republic of Indonesia. The authors would thank the Faculty of Computer Science and Directorate of Research and Community Engagement of Universitas Indonesia for their continuous support to this project.

\section{References}

Abdelrahman, M., Papmichail, K. N., \& French, S. (2011). Knowledge management system's characteristics that facilitate knowledge sharing to support decision making processes in multinational corporations. In Proceedings of the AMCIS 2011.

Alavi, M., \& Leidner, D. E. (2001). Knowledge management and knowledge management systems: Conceptual foundations and research issues. MIS Quarterly, 25(1), 107-136.

Bailey, J. E., \& Pearson, S. W. (1983). Development of a tool for measuring and analyzing computer user satisfaction. Management Science, 29(5), 530-545.

Basten, D., Schneider, L., \& Michalik, B. (2013). Knowledge contribution motivators An expectation-confirmation approach. In Proceedings of the Thirty-Fourth International Conference on Information Systems. Milan, Italy.

Becerra-Fernandez, I., \& Sabherwal, R. (2010). Knowledge management: Systems and processes. New York, NY: M.E Sharpe, Inc.

Belanger, F., Hiller, J. S., \& Smith, W. J. (2002). Trustworthiness in electronic commerce: The role of privacy, security, and attributes. Journal of Strategic Information Systems, $11(3 / 4), 245-270$.

Bera, P., \& Wand, Y. (2009). A framework to clarify the role of knowledge management systems. In Proceedings of the PACIS 2009.

Bhattacherjee, A. (2001). Understanding information systems continuance: An expectation-confirmation model. MIS Quarterly, 25(3), 351-370.

Bossen, C., Jensen, L. G., \& Udsen, F. W. (2013). Evaluation of a comprehensive EHR based on the DeLone and McLean model for IS success: Approach, results, and success factors. International Journal of Medical Informatics, 82(10), 940-953.

Casaló, L.V., Flavián, C., \& Guinalíu, M. (2008). The role of satisfaction and website usability in developing customer loyalty and positive word-of-mouth in the e-banking services. International Journal of Bank Marketing, 26(6), 399-417.

Chea, S., \& Luo, M. M. (2008). Post-adoption behaviors of e-service customers: The interplay of cognition and emotion. International Journal of Electronic Commerce, 
12(3), 29-56.

Chin, W. W. (1998). The partial least squares approach to structural equation modeling. In G. A. Marcoulides (Ed.), Modern Methods for Business Research (pp. 295-336). Mahwah, NJ: Lawrence Erlbaum Associates.

Chin, W. W. (2010). How to write up and report PLS analysis. In V. Esposito Vinci, W. W. Chin, J. Henesler, \& H. Wang (Eds.), Handbook of Partial Least Square (pp. 655688). New York, NY: Springer.

Chiu, C.-M., Hsu, M.-H., Lai, H., \& Chang, C.-M. (2012). Re-examining the influence of trust on online repeat purchase intention: The moderating role of habit and its antecedents. Decision Support System, 53(4), 835-845.

Choi, N. (2009). How loyal are you? Continuance intention and word of mouth in free/libre open source software. Paper presented at the AMCIS 2009 Doctoral Consortium.

Chu, S.-C., \& Kim, Y. (2011). Determinants of customer engagement in electronic wordof-mouth. International Journal of Advertising, 30(1), 47-75.

Cofriyanti, E., \& Hidayanto, A. N. (2013). The relationship among organizations' factors, information technology, innovation and performance: An Indonesian SMEs study. International Journal of Innovation and Learning, 14(3/4), 422-443.

Dabholkar, P. A., Shepard, C. D., \& Thorpe, D. I. (2000). A comprehensive framework for service quality: An investigation of critical conceptual and measurement issues through a longitudinal study. Journal of Retailing, 76(2), 139-173.

Davis, F. D., Bagozzi, R. P., \& Warshaw, P. R. (1989). User acceptance of computer technology: A comparison of two theoretical model. Management Science, 35(8), 982-1003.

DeLone, W. H., \& McLean, E. R. (1992). Information systems success: The quest for the dependent variable. Information Systems Research, 3(1), 60-95.

DeLone, W. H., \& McLean, E. R. (2003). The DeLone and McLean model of information systems success: A ten-year update. Journal of Management Information System, 19(4), 9-30.

DeWitt, T., Nguyen, D. T., \& Marshall, R. (2008). Exploring customer loyalty following service recovery the mediating effects of trust and emotions. Journal of Service Research, 10(3), 269-281.

Dick, A. S., \& Basu, K. (1994). Customer loyalty: Towards an integrated conceptual framework. Journal of Academy of Marketing Science, 22(2), 99-113.

Dijkstra, T. (1983). Some comments on maximum likelihood and partial least squares methods. Journal of Economics, 22, 67-90.

Dong, T.-P., Cheng, N.-C., \& Wu, Y.-C. J. (2014). A study of the social networking website service in digital content industries: The Facebook case in Taiwan. Computers in Human Behaviour, 30, 708-714.

Ercis, A., Unal, S., Candan, F. B., \& Yildirim, H. (2012). The effect of brand satisfaction, trust and brand commitment on loyalty. Procedia - Social and Behavioral Sciences, $58,1395-1404$.

Farzaneh, N., \& Shamizanjani, M. (2014). Storytelling for project knowledge management across the project life cycle. Knowledge Management \& E-Learning, 6(1), 83-97.

Flavian, C., Guinalıu, M., \& Gurrea, R. (2006). The role played by perceived usability, satisfaction, and consumer trust on website loyalty. Information \& Management, 43(1), 1-14.

Gefen, D. (2004). What makes an ERP implementation relationship worthwhile: Linking trust mechanisms and ERP usefulness. Journal of Management Information Systems, 21(1), 263-288. 
Ghazali, I., \& Latan, H. (2012). Partial least squares: Konsep, Teknik dan Aplikasi Menggunakan Program SmartPLS 2.0 M3. Semarang: Badan Penerbit Universitas Diponegoro.

Graf, R., \& Perrien, J. (2005). The role of trust and satisfaction in a relationship: The case of high tech firms and banks. Paper presented at Conference of the European Marketing Academy (EMAC). Munich, Germany.

Hair, J. F., Black, W. C., Babin, B. J., \& Anderson, R. E. (2010). Multivariate data analysis (7th ed.). New York, NY: Pearson Prentice Hall.

Hair, J. F., Ringle, C. M., \& Sarstedt, M. (2011). PLS-SEM: Indeed a silver bullet. Journal of Marketing Theory and Practice, 19(2), 139-152.

Hashim, K. F., Tan, F. B., \& Andrade, A. D. (2012). The role of trust and commitment in continuous knowledge contribution intention within business online communities. In Proceedings of the CONF-IRM 2012.

He, W., \& Wei, K.-K. (2009). What drives continued knowledge sharing? An investigation of knowledge-contribution and -seeking beliefs. Decision Support Systems, 46(4), 826-838.

Hidayanto, A. N., Limupa, A., Junus, K. M., \& Budi, N. F. A. (2015). Investigating knowledge sharing behaviour on virtual community members: Integration of technological, individual and contextual factors. International Journal of Business Information Systems, 19(2), 180-204.

Hsu, C.-L., \& Lin, J. C.-C. (2015). What drives purchase intention for paid mobile apps? - An expectation confirmation model with perceived value. Electronic Commerce Research and Applications, 14(1), 46-57.

Ives, B., Olson, M. H., \& Baroudi, J. J. (1983). The measurement of user information satisfaction. Communications of the ACM, 26(10), 785-793.

Jennex, M. (2005). The issue of system use in knowledge management systems. In Proceedings of the 38th Hawaii International Conference.

Jennex, M., \& Olfman, L. (2003). A knowledge management success model: An extension of DeLone and McLean's IS success model. In Proceedings of the AMCIS 2003.

Kim, C., Zhao, W., \& Yang, K. H. (2008). An empirical study on the integrated framework of e-CRM in online shopping: Evaluating the relationships among perceived value, satisfaction, and trust based on customers' perspectives. Journal of Electronic Commerce in Organizations, 6(3), 1-19.

Kim, H.-W., Xu, Y., \& Koh, J. (2004). A comparison of online trust building factors between potential customers and repeat customers. Journal of the Association for Information Systems, 5(10), 392-420.

Kim, J., Hong, S., Min, J., \& Lee, H. (2011). Antecedents of application service continuance: A synthesis of satisfaction and trust. Expert System with Application, 38(8), 9530-9542.

Kulkarni, U. R., Ravindran, S., \& Freeze, R. (2007). A knowledge management success model: Theoretical development and empirical validation. Journal of Management Information Systems, 23(3), 309-347.

Lee, Y., \& Kwon, O. (2011). Intimacy, familiarity and continuance intention: An extended expectation-confirmation model in web-based services. Electronic Commerce Research and Applications, 10(3), 342-357.

Leung, N. K. Y., Shamsub, H., Tsang, N., \& Au, B. (2015). Using knowledge management to improve learning experience of first-trimester students. Knowledge Management \& E-Learning, 7(2), 297-315.

Li, H., \& Liu, Y. (2011). Post-adoption behaviour of e-service users: An empirical study on Chinese. In Proceedings of the ECIS 2011.

Lin, C. S., Wu, S., \& Tsai, R. J. (2005). Integrating perceived playfulness into 
expectation-confirmation model for web portal context. Information \& Management, 42(5), 683-693.

Lin, T-C., Wu, S., Hsu, J. S-C., \& Chou, Y-C. (2012). The integration of value-based adoption and expectation-confirmation models: An example of IPTV continuance intention. Decision Support Systems, 54(1), 63-75.

Liu, S. C. (2003). A study of factors that facilitate use of knowledge management systems and the impact of use on individual learning. Unpublished doctoral dissertation, Claremont Graduate University, Claremont, CA.

Maccoby, M. (2003). The seventh rule: Creating a learning culture. Research Technology Management, 46(3), 59-60.

McKinney, V., Yoon, K., \& Zahedi, F. M. (2002). The measurement of web-customer satisfaction: An expectation and disconfirmation approach. Information Systems Research, 13(3), 296-315.

McKnight, D. H., Choudhury, V., \& Kacmarc, C. (2002). The impact of initial consumer trust on intentions to transact with a web site: A trust building model. Journal of Strategic Information Systems, 11(3/4), 297-323.

Mooradian, T. A., \& Oliver, J. M. (1997). "I can't get no satisfaction": The impact of personality and emotion on postpurchase processes. Psychology and Marketing, 14(4), 379-393.

Moos, B., Beimborn, D., Wagner, H.-T., \& Weitzel, T. (2011). Knowledge management system absorptive capacity, and innovation success. In Proceedings of the ECIS 2011.

Morgan, R. M., \& Hunt, S. D. (1994). The commitment-trust theory of relationship marketing. Journal of Marketing, 58(3), 20-38.

Oliver, R. L. (1980). A cognitive model for the antecedents and consequences of satisfaction decisions. Journal of Marketing Research, 17(4), 460-469.

Oliver, R. L. (1993). Cognitive, affective, and attribute bases of the satisfaction response. Journal Consumer Research, 20(3), 418-430.

Pai, J. C., \& Zou, L. H. (2013). An empirical study of factors influencing the use of knowledge management system in a public sector organization. International Journal of E-Business Development, 3(2), 56-63.

Ranaweera, C., \& Prabhu, J. (2003). On the relative importance of customer satisfaction and trust as determinants of customer retention and positive word of mouth. Journal of Targeting, Measurement and Analysis for Marketing, 12(1), 82-90.

Reichheld, F. F. (2003). The one you need to grow. Harvard Business Review, 81(12), 46-54.

Seddon, P. B. (1997). A respecification and extension of the DeLone and McLean model of IS success. Information Systems Research, 8(3), 240-253.

Shiau, W.-L., \& Luo, M. M. (2012). Factors affecting online group buying intention and satisfaction: A social exchange theory perspective. Computers in Human Behaviour, 28(6), 2431-2444.

Singh, J., \& Sirdeshmukh, D. (2002). Agency and trust mechanisms in consumer satisfaction and loyalty judgements. Journal of the Academy of Marketing Science, 28(1), 150-167.

Standing, C., \& Benson, S. (2000). Organisational culture and knowledge management. In Proceedings of the PACIS 2000.

Stone, R. W., \& Baker-Eveleth, L. (2013). Students' expectation, confirmation, and continuance intention to use electronic textbooks. Computers in Human Behavior, 29(3), 984-990

Sucahyo, Y. G., Utari, D., Budi, N. F. A., Hidayanto, A. N., \& Chahyati, D. (2016). Knowledge management adoption and its impact on organizational learning and nonfinancial performance. Knowledge Management \& E-Learning, 8(2), 387-413. 
Szymanski, D. M., \& Henard, D. H. (2001). Customer satisfaction: A meta-analysis of empirical evidence. Journal of the Academy of Marketing Science, 29(1), 16-35.

Tha, K. K. O., Poo, C.-C. D., \& Yu, X. (2009). Understanding continuance intention in elearning community. In Proceedings of the AMCIS 2009.

Thong, J. Y. L., Hong, S.-J., \& Tam, K. Y. (2006). The effects of post-adoption beliefs on the expectation-confirmation. International Journal of Human-Computer Studies, 64(9), 799-810.

Tiwana, A., \& Bush, A. A. (2005). Continuance in expertise-sharing networks: A social perspective. IEEE Transaction on Engineering Management, 52(1), 85-101.

Tona, O., Carlsson, S., \& Eorn, S. (2012). An empirical test of DeLone and McLean's information system success model in a public organization. In Proceedings of the AMCIS 2012.

Trochim, W. M. K. (2000). Research methods knowledge base (2nd ed.). Cincinnati, OH: Atomic Dog Publishing.

Weiss, H. M., \& Cropanzano, R. (1996). Affective events theory: A theoretical discussion of the structure, causes and consequences of affective experiences at work. In B. M. Staw \& L. L. Cummings (Eds.), Research in Organizational Behavior: An Annual Series of Analytical Essays and Critical Reviews (vol. 18, pp. 1-74). London, UK: JAI Press.

Widiyanto, N., Sandhyaduhita, P. I., Hidayanto, A. N., \& Munajat, Q. (2016). Exploring information quality dimensions of government agency's information services through social media: A case of the Ministry of Education and Culture in Indonesia. Electronic Government, an International Journal, 12(3), 256-278.

Wu, J.-H., \& Wang, Y.-M. (2006). Measuring KMS success: A respecification of the DeLone and McLean's model. Information \& Management, 43(6), 728-739.

Zhang, Y., Fang, Y., Wei, K.-K., \& Chen, H. (2010). Exploring the role of psychological safety in promoting the intention to continue. International Journal of Information Management, 30(5), 425-436. 